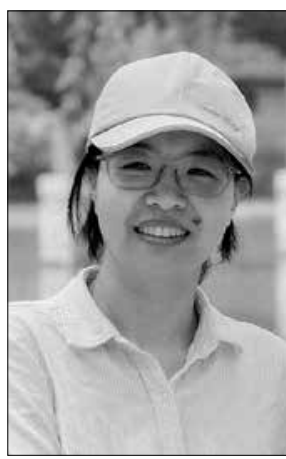

https://doi.org/10.24101/logos.2020.15

Gauta 20190919

MIN SUN

Nankino universitetas, Kinija

Nanjing University, China

\title{
M. K. ČIURLIONIO IR KINŲ TAPYBOS ESTETIKA IŠ "YUN" KATEGORIJOS PERSPEKTYVOS
}

\author{
The Aesthetics of M. K. Čiurlionis and Chinese Paintings \\ from the Perspective of "Yun" Category
}

\section{SUMMARY}

Taking the most important concept of Chinese aesthetics - yun 韵 - as the object of study, this paper explores its two core connotations or different levels of meaning - 1) the "elegance/refinement" ya 雅 and 2) „inexhaustible more“ you yu bu jin 有余不尽. The paper explores how yun is expressed in art by taking several classical Chinese paintings and analyzing them from the point of view of three Chinese aesthetic concepts: 1) dan 淡 (bland, as in "suave“, "smooth", "unperturbed“, "soothingly pleasing", 2) kong bai yu liu dong 空白与流动 ("unfilled space and movement“) and 3) ping heng 平衡 („balance“). Then the same principle of yun is used to analyze the paintings of Lithuanian artist M.K.Čiurlionis in comparison with Chinese paintings. Through the analysis and comparison of the paintings it isconcluded that the art of Čiurlionis shares core principles with traditional Chinese paintings; moreover, the yun category can be used as a subtle aesthetic measure of both Chinese and non-Chinese masterpieces of art.

\section{SANTRAUKA}

Straipsnyje įvairiais aspektais analizuojama pamatinė kinų tapybos estetikos yun 韵 kategorija ir detaliai aptariamos dvi svarbiausios jos semantinès prasmės - „elegantiškumas“ ya 雅 ir "neišsemiamas daugiau“ you yu bu jin 有余不尽. Vadovaujantis pateiktos teorinės koncepcijos nubrěžtomis gairèmis, pasitelkiant ir vaizdinės raiškos galimybes bei atsižvelgiant ị konkretų kinų tradicinės kultūros, mąstymo tradicijos kontekstą, analizuojami ne tik keli kinų klasikinès tapybos kūriniai, tačiau ir išryškinamos sąsajos su M. K. Čiurlionio tapybos estetiniais principais. Straipsnyje, analizuojant Yun kategorijos raiškos formas kinų tradicinėje tapyboje, išryškinami trys pagrindiniai skiriamieji bruožai - „prėskumas" dan 淡, „neužpildyta (tuščia) erdvè ir 
judesys" kong bai yu liu dong 空白与流动 bei "pusiausvyra“ ping heng 平衡. Yun analizė užbaigiama ne kinų tapybos, o Čiurlionio kūrinių aptarimu, taikant jiems tuos pačius yun kategorijos estetinio vertinimo kriterijus, ir pažymint, kad šio lietuvių menininko kūryba turi daug bendra su kinų ir jos įtaką patyrusia Rytụ Azijos estetika.

\section{IVADAS}

Qinyun 气韵 yra viena pamatinių kinu tradicinès tapybos estetikos kategorijų. Vienas didžiujų kinų tapybinès estetikos pradininkų Xie He (479-502) 谢赫 iškèlè šią estetinę idèją ankstyvojo kinų tapybos teorijos laikotarpio etapiniame veikale Užrašai apie senosios tapybos squokas (Xie 1-2), kitas žymus Tang dinastijos menininkas ir teoretikas Zhang Yanyuan (815-907) 张彦远 rèmėsi ja savo knygoje Istoriniu tapybos kūriniu užrašai (Zhang 119), o tapytojas Jing Hao (850-911), pasitelkęs ją tekste Užrašai apie teptuko valdymo būdus (Lu 6), vertino peizažinès tapybos kūrinius. Qiyun sąvokos vartojimo laukas kinu estetikos ir meno tradicijoje nuolatos plètėsi, pamažu èmè aprépti ivvairaus žanro tapybos kūrinius - nuo portretinès iki peizažinès tapybos, o galiausiai įsiskverbè i̇ visas kinų tapybos sritis bei tapo kiniškos tapybos svarbiausiu vertinimo kriterijumi. Galima sakyti, kad jeigu nesuprasime qiyun, negalèsime perprasti ir kinu tapybinès estetikos dvasios ir nesuvoksime, kodèl ji yra būtent tokia. Gvildenant qiyun semantinių prasmių lauką pirmiausia tikslinga atkreipti demesi, kad Jing Hao Užrašuose apie teptuko valdymo būdus pirmą kartą sujunge $q i$ 气 ir yun 韵 sąvokas i vieną. Vadinasi, qi ir yun yra tuo pačiu savarankiškos estetinès kategorijos. Vèliau, po Song dinastijos meno, eruditai wen ren 文人vertindami tapybą èmé plačiai sekti Jing Hao pavyzdžiu, taigi nenusižengiant tiesai, galima teigti, kad yun kategorija intelektualu (meno eruditų) kultūrineje erdvejje tapo svarbiu tapybos estetinès vertės kriterijumi. Tad tik perpratus yun galima visiškai ir iš esmès suprasti qiyun, o kartu suvokti ir kinų tapybinès estetikos tikrają esmę.

\section{YUN SEMANTINIŲ PRASMIŲ LAUKAS}

Istoriškai yra trys pagrindinès yun sampratos: 1) darna, 2) rezonansas ir 3) ritmas. Visos šios trys sampratos neabejotinai glaudžiai susijusios su muzika. Čia svarbu prisiminti, kad wen ren 文人, rafinuotu, puikiai ivvairiose meno srityse išsilavinusių kinų kultūros tradicijų saugotojų (Vakarų estetikos tradicijoje dažniausiai vadinamu „intelektualais“) aplinkoje muzika ir tapyba, kartu su kaligrafija ir poezija, visada buvo neatsiejamos, o jų estetiniai idealai dažniausiai labai panašūs ar netgi tapatūs. Todèl, gilindamiesi ì yun kategorijos sklaidą tapybos plotmèje, galime tai susieti su yun raiška muzikos srityje. Ming dinastijos grojimo liutnia meistras Xu Shangying 徐上瀛 (1582-1662) veikale apie muziką Xi Shan Qin Kuang 溪山琴况 poetiškai apibūdina garso „magiją: „,Be- 
sidriekiantis ị tolius garsas, Pavirsta subtiliai tyliu, Jo nežinai ir negirdi, Tačiau jis skamba amžinai" (Xu 2010).

Xu Shangying šiomis eilèmis apibūdina muzikos garsų estetiką kaip tam tikrą ,yun", ir ši muzikos garsu yun ivvardijama kaip you yuan 悠远 - „be galo tolima“, „ilgalaikiška“, ,i tolius besitęsianti" erdvè, kurioje tarsi pasislepia ir kurią užpildo nuskambèjęs garsas. Ieškant efektyvių kelių tokiai estetinei pagavai išreikšti, pasitelkiama kinų filosofijos idèja, jog garso judesyje glūdi rimtis, o ši rimtis pirmiausia išreiškiama kaip pauzė arba tyra erdvė. Tačiau ši tyra, neužpildyta erdvė neatsiranda staiga, viską pašalinus, bet suformuojama pamažu ir iš lèto, paliekant ìspūdi, lyg dar ten kas yra, nors lyg jau nieko ir nebeliko. Toje erdvèje išlieka begarsio rankos judesio ispūdis. Muzika - tai judesiai ją atliekančiojo širdyje, kurie sukuria pojūti lyg judesys vienu metu ir liautųsi, ir toliau tęstusi (kin. zhi er bu zhi 止而不止).

Lygiai taip ir tapyboje yun drobeje turi panašių savybių, jai būdinga rimtis, kurią papildo qi tekèjimas, sukeliantis estetini pojūtị. Aukšto lygio tapybos kūrinys, kuriame glūdi yun, panašiai kaip ir yun muzikoje, stebėtojui palieka neribotą kūrybinès vaizduotès erdvę. Yun fenomenas tapyboje ir muzikoje dažnai apibūdinamas kaip „niekada neišsibaigiantis ir potencialiai dar daugiau" besiskleidžiantis you yu bu jin 有余不尽. You $y u$ - tai perteklius, "dar daugiau“, tapybos kūrinyje pasireiškia kaip tam tikri meninès kūrybos procese atsirandantys nedideli papildomi meno kūrinio elementai. Bu jin yra tai, kas neišsakyta, neišbaigta, negali būti išbaigta, tačiau skleidžiasi neišsakymo, estetinès užuominos pavidalu, o tapyboje - tai, ko ten vizualiai nèra arba trūksta. Šie dalykai atspindi kinu tapybos "daug“ duo 多 ir „mažai“ shao 少 filosofiją. Žinoma, galima iš karto klausti, o ko yra „dar daugiau“? Atsakymas būtų, kad tapybos kūrinys suteikia daugiau pojūčių nei vien tik tai, kas akivaizdžiai matoma, tapybos kūrini galima išgirsti, užuosti, sugriebti ne vien rega. "Dar daugiau“ - tai tapybos kūrinio perteikiamas platesnis dvasinis meno turinys ir kontekstas, be vizualaus vaizdavimo, dar yra poezija ir muzika. Kinų tradicinè tapyba tarsi siekia suimti visus penkis pojūčius, taip pat ir poeziją. Bu jin kaip neišbaigtumas, estetinè užuomina reiškia sąmoningą tam tikrų konkrečių detalių praleidima, kadangi kuo labiau ištapoma drobè, kuo viskas pavaizduojama tiksliau, kuo ten atsiranda daugiau detaliu, tuo labiau prarandamos lakios vaizduotés polékiu erdvés.

Vadinasi, yun sąvoka iš esmès siekiama „ribotoje paveikslo erdvejje perteikti neišsemiama, neišsakomą žodžiais minti”“ (画有尽而意无穷). Toks „minties“ $y i$ 意 ir „vaizdo“ xiang 象 santykis, kai per ribotą formą išreiškiama neribota intencija, yra pamatinis tradicinès kinų tapybinès estetikos bruožas. Vienas žinomas iš pirmųjų daoizmo klasikos komentuotojų Wang Bi 王㢶 (226-249) šitaip nusako „vaizdo“ sąvoką: „Vaizdas yra minties išraiška iš išorinio pasaulio pasirenkant daiktą ar įvykį. Jis yra priemonė išreikšti minti ir perduoti bendram vartojimui" (Wang 1781). Kinu tapybos „vaizdo“ $x i$ ang 象 sąvoka dabartinejje kinų kalboje būtent ir vadinama yi xiang 意象, o tai reiškia idèją arba minties vaizdą. Paveiksle nutapytas "vaizdas" xiang turi būtent papasakojimo paskirti, jis nebèra grynas gamtos daiktas, bet tampa daikto vaizdo ir menininko vidinès pajautos 
sinteze. Yun 韵 - tai virsmas, kai daiktas tampa vaizdu xiang 象, o paskui iš vaizdo transformuojasi i neribotą minti y $i$ 意. Dar kitaip tariant, dèl yun vaizdas, turintis neišsemiamą minties prasmę, tampa neišsemiamos minties prezentacija.

Tačiau sugrižžtant prie mūsų straipsnio pradžioje aptarto Xie He gyvenamojo laikotarpio ir tuo metu vyravusios žmogaus charakterio ivvertinimo praktikos, yun iš pradžių buvo vartojama kaip žmogaus etinès kultūros lygio vertinimo kriterijus. Be jokiu abejonių, Xie He, ivertindamas autentiško (tikro) menininko kūryba, pasitelkdavo būtent yun sąvoką. Yun kaip esminių žmogaus charakterio savybių apibūdinimas susiformavo Xuan Xue 玄 学 (liet. Mokymas apie misteriją) ittakai veikiant. Šia sąvoka galima apibūdinti konkretaus žmogaus bendros vidinès laikysenos ir elgesio kultūrą. Jei žmogus turi yun, vadinasi, jis nèra grubus ir ikūnyja tam tikrą subtilumo ir gracijos feng ya 风雅 groži. Šis subtilios gracijos siekis ya 雅 išsilavinusių žmonių tapyboje wen ren hua 文人画 pasireikšdavo itin delikačiomis tapymo išraiškomis. Wen ren hua tapybos yun yra vienas aukščiausių kriteriju, tai būtent vadinamoji ya subtili gracija, o tapybos esmę galima suprasti kaip užmoji perteikti aukštos kūrybos pojūtị.

Apibendrinant išsakytas mintis galima teigti, kad yun turi du svarbius as- pektus arba lygmenis: 1) ya (liet. elegancija, gracija, subtili ir graži elgsena) aspektas, kuris suteikia yun esmei tam tikras gaires ar netgi taisykles, o yun aukščiausia išraiška yra aukštos kūrybos arba išsilavinusio žmogaus wen ren elegancijos perduodamas tam tikras "skonis“ arba pojūtis. Jeigu susumuotume antikos veikalų apie tapybą aprašymus, juose visur yun nurodo tam tikrą išsilavinusio žmogaus dvasini siekị. O kalbant apie atskiro žmogaus dvasinius, taigi vidinius, siekius lengviau suprasti ir paaiškinti, kodèl yun, viena vertus, taip sunku konkrečiai apibūdinti, o antra vertus, padeda kaip apibrèžta, konkreti, iš kartos ị kartą nuolatos perduodama vertinimo idejja. Nesvarbu, kokiais skirtingais žodžiais ji būtų apibūdinama, jos šerdis nesikeičia. Ši šerdis būtent ir yra išsilavinusio žmogaus estetinè pajauta. Ji lemia, kodèl tam tikras paveikslas turi yun, o kitas neturi. 2) You yu bu jin kaip „niekada neišsibaigiantis daugiau“ aspektas apibrěžia tapybos kūrinio visumini estetinį rezultatą. Kitais žodžiais, kalbant apie meno kūrini, tik tas kūrinys, kuris ịkūnyja ši you yu bu jin aspekta, turi yun. Po apibendrinimo nuosekliai kyla klausimas, kokiais būdais menininkas gali išreikšti ši „niekada neišsibaigianti daugiau"? Kokios savybès būdingos tokio pobūdžio meninei išraiškai? Tai ir yra trečios dalies tema.

\section{YUN SKLAIDA TAPYBOJE}

\section{Prèskumas dan 淡}

Dan kaip prèskumas iš pradžių reiškè vyno prèskumą. „Grafemų paaiškinimas ir rašmenu analizè" Shuo wen jie zi taip aiškina: „Švelnus skonis. Stipraus [sko- nio] priešingybè. [Vyną sudarantis radikalas] 酉 reiškia: stiprus - tai stipraus [skonio] vynas." Yun juk taip pat reiškia tam tikra "skoni“" yun wei 韵味. Vadinasi, yun apibūdinimui mes taip pat vartojame skonio sąvoką. Tik paveikslo yun 


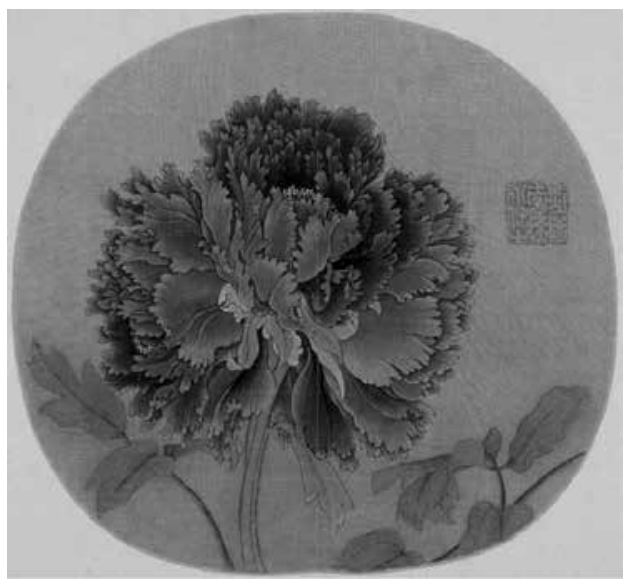

Bijūno paveikslas

skonio „skanavimas“ ir vyno skanavimas skiriasi, nes geras vynas yra stiprus, o geras paveikslas yra „prèskas“. Skonio prèskumas reiškia, kad jutimas smarkiai nedirgina skonio receptorių, nesukelia aštrių pojūčių. Prèskumas regos atžvilgiu turi du lygmenis:

1. Lygmuo, susijęs su spalva. Kinų tapybos spalvų estetikoje yra labai ryškus tapybos lygmenų atskyrimas. Vyrauja įsitikinimas, kad spalvų paprastumas, jų santūrumas yra estetiniu požiūriu geriau negu įvairovè, net spalvos nebuvimas yra geriau už spalvą (juk toks yra tapybos meninės išraiškos instrumentas tušas). Tang dinastijos garsus poetas ir dailininkas Wang Wei 王维 (701-761 arba 699-761) daugelio pripažintame veikale Peizažinés tapybos metodai Shan shui jue 《山水诀》 rašè: „Tapybos Kelyje Dao tušas yra svarbiausias" (Wang ir Zhao). Palyginti su spalvingu paveikslu, paveiksle, nutapytame vien tik juodu tušu, yra daugiau yun. Natūraliai gali kilti klausimas, kodèl taip yra. Gali būti dèl daoistinès minties poveikio, kadangi pamatiniame daoizmo veikale Laozi sako-

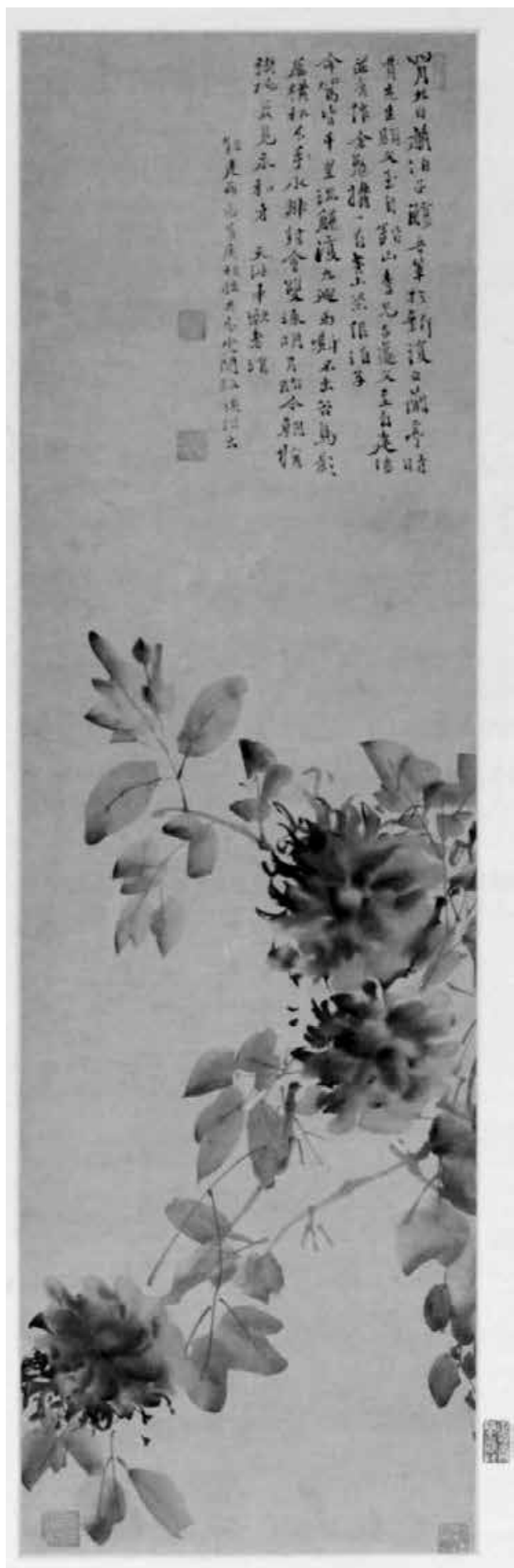

XU Wei. Bijūno paveikslas, nupieštas tušu 
ma: „Penkios spalvos žmogų apakina“ (Chen 1984). Kitaip tariant, manoma, kad ryškios spalvos turi įtakos mūsų pasaulio pažinimui, jos pririša aki tik prie matomo fenomeno. Norint iš tiesų pažinti pasauli, svarbu, daoistiniais terminais tariant, fan pu gui zhen 返璞归真 (liet. atsisukti i paprastumą ir sugrižti i tai, kas tikra). Juodas tušas nèra daikto tikroji spalva, bet būtent todèl jis gali išryškinti daikto tikruosius kontūrus. Tapyba tušu taip pat nèra vien tik juodos ir baltos spalvos, bet turi turtingą atspalvių îvairovę, juk tradiciškai tušas skirstomas i penkis atspalvius. Tušas taip pat suteikia turtingą ivvairovę juodai spalvai keistis i baltą ir atvirkščiai. Pavyzdžiui, šie kismai akivaizdūs vadinamosiose "sauso teptuko"

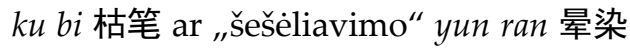
technikose. Juodas tušas apima turtingą spalvu pasauli, bet tuo pačiu ir pranoksta ji sufokusuodamas vaizdą i daiktų tikroviškesnius aspektus. Juodo ir balto tarpusavio transformacijos, pokyčiai tapybos kūrinyje tam tikra prasme yra Taiji 太极 simbolio dvieju - yin ir yang - pradų virsmų tęsinys pojūčių pasaulyje.

2. Lygmuo, susijęs su vaizdu arba atvaizdu xing xiang 形象. Pirmiausia kalbant apie tapybos kūrinio pagrindini vaizduojamą daiktą ar reiškini, kuo jis vaizduojamas paprasčiau, su kuo mažiau ji puošiančių ir detalizuojančių priedų, tuo jis yra gražesnis. Poeto Libai 李白 (701-762) žodžiais tariant, „[Taip, kaip] vanduo išplauna maurus, [taip] natūralumas pašalina [dirbtinius] papuošimus" 清水出芙蓉, 天然去雕饰. Tai parodo, kad kinų išsilavinusiems intelektualams wen ren būdingas specifinis estetinis idealas. Ju akimis žvelgiant, paprastas, be jokiu papuošimu daiktas yra kur kas gražesnis nei daiktas, pilnas spalvu ir ivairiausiu ji „puošiančiu“" priedu ar kitu ryškiu detaliu. Pasitelkę kitą daoistinį veikalą Zhuangzi pacituosime: „Pasaulyje niekas negali galinètis su paprastumo grožiu“, „Visa, kas gražu, seka neturintị ribų natūralų prèskumą" (Guo, 2015). Toliau, kūrinio pagrindinis vaizduojamasis elementas negali būti pernelyg išsiskiriantis, pasak dailininko Jing Hao 荆浩 (850-911), „yun esti tai, kai paslèpti pédsakai nustato formą" (Lu 6). Pagrindinis vaizduojamas objektas negali užimti centrinès vietos, jis turi sąveikauti su visais kitais paveiksle esančiais elementais, netgi su jais sudaryti vieną visumą, turinčią gilesnę potekstę, o stebètojui duoti galimybę estetiškai grožètis tuo, kas gali būti patirta dvasine patirtimi, bet negali būti ivardijama žodžiais. Kadangi kalbama apie „dvasinę patirtic yi hui 意会, vadinasi, tai, kas perduodama kūriniu, negali būti tiksliai įvardijama, nes tai yra tam tikras subtilus pojūtis, perduodama tam tikra kūrybinè mintis yi jing 意境, kuriai reikalinga gili vidinè pajauta - kiniškai vadinama $w u$ 悟.

Apibendrinant galima sakyti, kad ir spalvu, ir vaizdavimo prèskumas yra skirtas: nugalèti formos apribojimus; atitrūkti nuo akivaizdumo, kuri mato akis; išvengti situaciju, kai tapytojas ir stebètojas pasineria į išorinès daikto ir reiškinio formos žavesi bei pamiršta daiktų ir reiškinių vidinę prigimtį.

Iliustruodami šias mintis konkrečiais pavyzdžiais galime tvirtinti, kad jeigu palygintume du paveikslus - „Bijūno paveikslo lapą" $M u$ dan tu ye 《牡丹图 页》ir tapytojo Xu Wei 徐渭 (1521-1593) 
"Juodai baltą bijūno paveikslą" Shui mo $m u$ dan $t u$ 《水墨牡丹图》, išsilavinusio žmogaus wen ren estetinès sampratos požiūriu, be jokių abejonių, antrasis juodai baltas paveikslas turi daugiau yun.

Paveiksle „Bijūno paveikslo lapas" $M u$ dan tu ye vaizduojamas bijūnas nupieštas pernelyg tikroviškai ir spalvingai, sutraukia visą demesi, bet jis tik atkuria stebètojui tikrovišką prasiskleidusị bijūną. Kitaip tariant, be to, ką matome, daugiau nieko kito nèra. $\mathrm{O} \mathrm{Xu}$ Wei "Juodai balto bijūno paveikslas" Shui mo $m u$ dan tu yra kitoks, ivvairiu atspalviu juodo tušo žiedlapių kontūrai leidžia mums patiems įsivaizduoti, kad kai kurie žiedlapiai jau pražydo, o kai kurių vis dar laukia žydẻjimo metas. Nors paveikslas ir bespalvis, tačiau tušo kaita leidžia mums pajusti žiedlapiu spalvos sodrumą ir sužydejjimo mastą. Visas paveikslas taip pat nesugriebia viso dèmesio fokuso, kiekviena gèlè, taip pat kiekviena gèlès šakelè bei lapelis susiję, o tarp gèlès ir jos šakeliu jaučiama tam tikra apykaita, galiausiai tai sukuria žaliuojančios lapijos jausmą.

\section{Neužpildyta erdvė ir judesys}

Song dinastijos tapybos teoretikas Fan Wen 范温 (tiksli gimimo ir mirties data nežinoma) yun sąvoką aprašo šitaip: "Gyvumu galima sugauti reiškinio dvasią, tačiau dvasią visiškai išreiškus nebelieka yun. Keliais teptuko mostais galima nupiešti legendinị drakono sūnų Suanni, ir nors piešinys, regis, paprastas, tačiau perteikia jo esmę. Jeigu būtu išpiešta kiekviena drakono detalè, nebeliktu vietos yun" (Guo 1980). Anot jo, yun esmè nèra pilnuma, bet neužpildymas. Aukštos

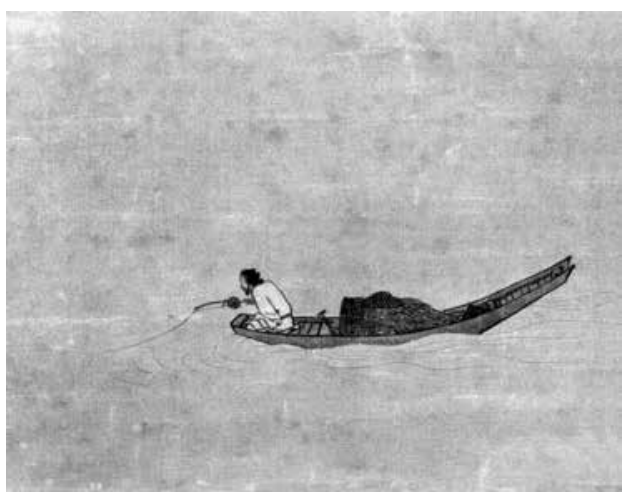

MA Yuan. Žiemą upėje vienišas žvejys

kultūros žmogus wen ren, vertinantis tapybą, kurioje atsispindi yun, pirmiausia apibūdina yun kaip tam tikrą neužpildymą laisvos vietos palikimą. Pavyzdžiui, Mayuan 马远 ir Xiagui 夏圭 tapybos kūriniai vèliau buvo vertinami kaip tokios yun tapybos klasika. Ju tapyboje patys vaizduojami daiktai drobèje užima labai nedidelę dali, o likusi didžioji dalis yra neužpildyta. Todèl tokiuose kūriniuose žiūrima ne tik i tai, kas nupiešta, bet i nupiešto objekto ir neužpildytos erdvès dinamiką.

Paveiksle „Žiemą upèje vienišas žvejys" Han jiang du diao tu 《寒江独钓图》 tai, kas nupiešta, tesudaro labai nedidelę visos drobès dali, jeigu žiūrèsime tik i seną žveji, nesuprasime, ką nori pasakyti tapytojas. Bet jeigu neužpildytą drobès dalị sujungsime su valtimi ir žveju, tai vizualiai pirmiausia pajusime, koks mažas čia yra žmogus. Meškerès valo, atidžiau nepažiūrëjus, net neižiūrėsi, o pažvelgę atidžiau matysime, kad valas nenugrimzdęs i vandenį, ir kartu tarsi sujungia piešini su neužpildyta erdve. Šalia valo keletas išlenktų trumpų ir plonų štrichų vaizduoja raibuliuojanti vandenį, o šalia valties keletas neryškiu 
bangų brūkšnių, tarsi ten ir būtų, ir nebūtų, sukuria pojūtị, lyg visas veiksmas ištirpsta i toli nusidriekiančiame rūke. Taigi šioje i tolumas išnyksiančioje dangaus ir žemès erdvèje vienas žmogus itin ramiai sẻdi valtyje ant kraštelio ir žvejoja. Keletas teptuko brūkšnių drobëje perteikia žmogaus vienišumą.

Kinų tapyba pasižymi unikaliu sugebejjimu pasitelkus tuščią drobę sukurti ypatingą gamtos, gamtos ir žmogaus sąryšio pojūtį. Atrodo, tapyba neužpildyta drobė saveikauja su tuo, kas nutapyta, ir šitaip sukuria turtingą išraiškingumą.

Šis didžiulès drobès erdvès ploto neužpildymas piešiniu kinų tapyboje yra nepaprastai svarbus filosofiniu ir estetiniu požiūriu, taip pat jis dažnai būna išskirtinis yun požymis. Paanalizuokime detaliau panašu piešinį tokiu pačiu pavadinimu, sukurtą kito menininko - Zhu Duan 朱端(Ming dinastija). Kontrasto požiūriu Zhu Duan piešinys šiek tiek atsilieka nuo Ma Yuan dèl šių priežasčių: Zhu Duan pateikia daug daugiau detaliú, i pagalbą pasitelkia šalia upès auganti medi, taip pat sniega kuris išreiškia „žiemos upę“, be to, dar jam svarbu, vaizduojant tikrovės daiktus ir jų santyki su žmogumi, išreikšti žmogaus vienišumą. Kitaip tariant, Zhu Duan vaizduotè dar nepranoko realybès pančiu ir nepakilo ì didesnès laisvès lygmenį.

Toliau, neužpildyta erdvė (vos pastebimas kalnų takelis, vingiuojantis upeliukas, galinga upès tèkmè) yra raktas, sutelkiantis kraštovaizdi i nedalomą visumą. Kai kalbame apie tapybos kūrini, kuriame nèra vieno aiškaus fokuso taško, pirmiausia žiūrime ì nenupieštas, neužpildytas dalis, dèl šių dalių akis ima

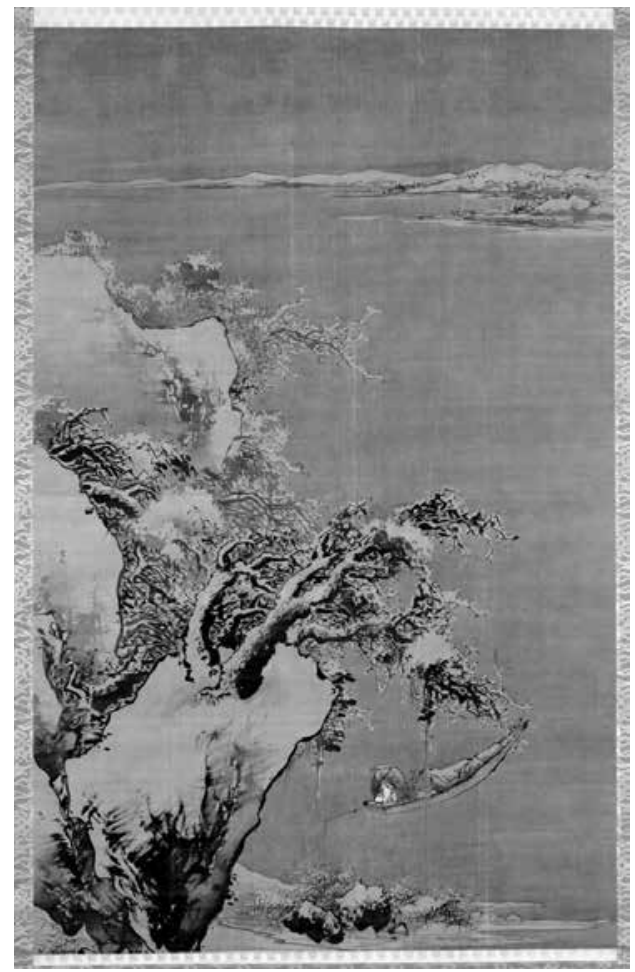

ZHU Duan. Žiemą upejje vienišas žvejys

judèti, taip pamažu sujungia visus piešinio elementus ì gyvą visumą.

Yuan ir Ming dinastiju sandūros laikotarpio tapytojo ir poeto Ni Zan 倪瓒 (1301-1374) epochai būdingo asketiško stiliaus paveiksle „Rudens paviljonas ir Jia medis" Qiu ting jia shu tu 《秋亭嘉树 图》dideli neužpildytos drobès plotai dèl paprastų nedidelių teptuko mostų sukuria gaivališkų vandens srautų tèkmès pojūtì, kartu sutelkia arčiau ir toliau vaizduojamas erdves $i$ visuma o tai galiausiai sukuria pojūtí, lyg žiūrètume i kitą upès krantą. Toliau esančio kalno kontūrai išnyksta horizonte, jie asocijuojasi su neužpildyta drobe, kartu išreiškia tam tikrą nepertraukiamą tęstinumą ir sukuria vingiuojantị bei išnykstanti estetinį vaizdą. 


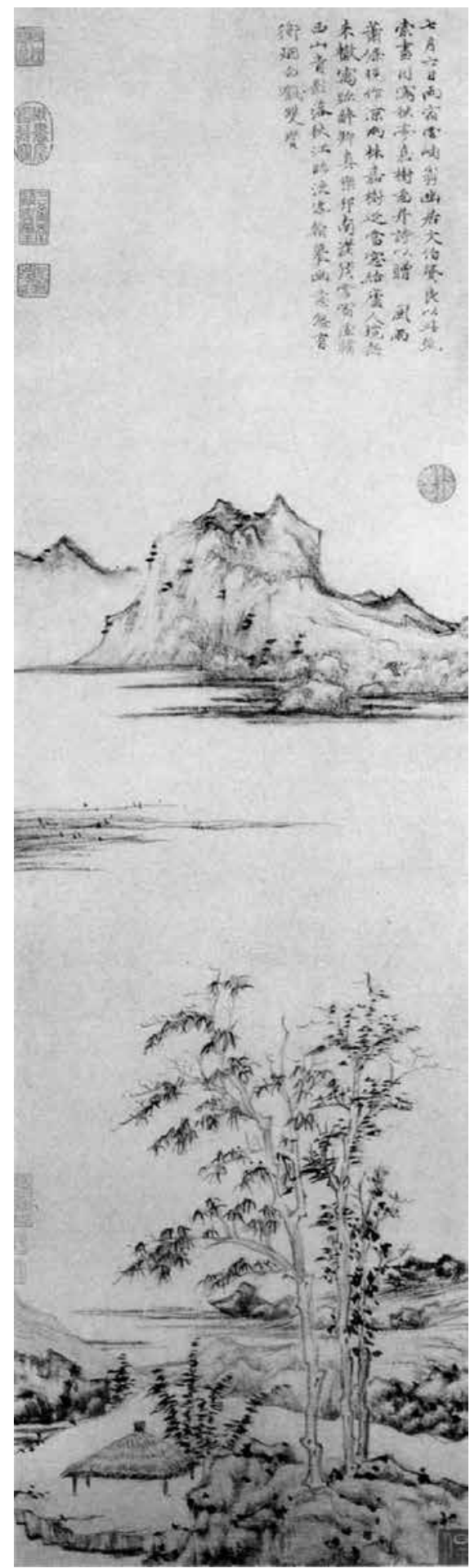

NI Zan. Rudens paviljonas ir Jia medis
Šis Ni Zan piešinys taip pat vaizduoja dar vieną plačiai vertinamą neužpildytos erdvès elementa, kuriame žmogaus nebuvimas suvokiamas kaip neabejotinas paveikslo estetinès vertès pranašumas - tai tuščias paviljonas ting 亭. Paviljono pirminè paskirtis yra poilsio vieta, akis tikisi tokioje vietoje išvysti žmogu, o ten nė gyvos dvasios. Ši neužpildyta erdvè paviljone turi didžiulę emocinio poveikio suvokejjui galia, todèl iš karto sugriebia žvilgsnį ir sukuria ypatingą vienatvès jausmo atmosferą. Atrodo, nèra nè vieno žmogaus, o visas peizažas persmelktas žmogaus vienatvès. Tai yra ta sunkiai žodžiais nusakoma neužpildytos erdvès ir estetinès užuominos galia.

Dèl šios neužpildytos erdvès galingo emocinio poveikio suvokëjui skleidžiasi jo žvilgsnio judejjimas, kuris kuria, steigia tam tikrą pojūtí, artimą „dvasinei kelionei“" galiausiai tai leidžia stebètojui gyvai patekti i paveikslo estetini pasauli ir, bestebint peizaža šia kelione mègautis ir ją išbaigti.

Intelektualų meno korifëjaus $\mathrm{Mi} \mathrm{Fu}$ sūnus ir mokinys Mi Youren 米友仁 paveiksle "Xiaoxiang upés nuostabus gamtovaizdis"Xiao xiang qi guan tu juan 《潚湘 奇观图卷》(tai „ritinio“ stiliaus kinu tapybos kūrinys, kuri reikia žiūrèti pamažu išvyniojant iš ritinio, ir pats kūrinys gali būti nuo vieno iki keliolikos metrų ilgio, čia pateikiama tik jo nedidelio fragmento iliustracija) taip pat dèl neužpildytos erdvės priverčia aki judèti ir patirti virsmą iš neužpildyto î užpildyta, ir atvirkščiai. Išvyniojant paveikslą akis pamažu juda ir regos fokusas šiame judejime tai pakyla aukštyn, tai nusileidžia, šitaip sukurdamas judèjimo debe- 
syse pojūti. Pradedant nuo debesu ir baigiant upès krantu, galiausiai pasiekiamas namas upès krante duoda užuominą sugrąžinti žvilgsni atgal, o žmonès ant kranto žiūri ị dangu, ir taip žvilgsnis vèl nukeliauja tolyn.

\section{Pusiausvyra}

Pažvelkime ì Xia Gui paveikslą Song yue fan xi tu 《松月泛溪图》. Nors šiame paveiksle nesilaikoma perspektyvos principu, tačiau išlaikyta paveikslo pusiausvyra. Kai žvilgsnis susitelkia i arčiau esančias pušis, atsiranda tam tikras nesvarumo pojūtis, dešinèje pasirodo maža valtelè, o aukštai tolumoje pasirodo vos vos matomas pilnas mènulis. Šių dvieju vaizdų sąveikos iš esmės yra universalus harmonijos principas, kitais žodžiais tariant, kairès ir dešinès, viršaus ir apačios pusiausvyra. Dar subtilesnis aspektas glūdi tame, kad šių dviejų vaizdų iškilimas praturtina viso piešinio pusiausvyros lygmenis: lengvo ir sunkaus, didelio ir mažo, tolimo ir artimo bei judančio ir rimties. Šitokia pusiausvyros išraiška atitinka yin ir yang energijos pradų niekada nesibaigiančią sąveiką ir kaitą.

Ko gero, dar svarbiau tai, kad valtelès ir pilnaties pasirodymas sukuria tarp skirtingų regos kampų atstuma, orientuoja ị didesnę neužpildytą erdvès dalį, o šis neužpildytumas yra tam tikras beribio pasaulio prieš mūsų akis atvèrimas. Tai ir yra yun pusiausvyra: kai neužpildytoje erdvèje netikètai pasirodo nedidelis objektas ir sudrumsčia erdvès ramybę bei realizuoja piešinio pusiausvyrą. Kartu tai nuolat nukreipia stebinčiojo žvilgsni dar tolyn, kur jis išnyksta begalinèje neužpildytoje erdvèje - besi-

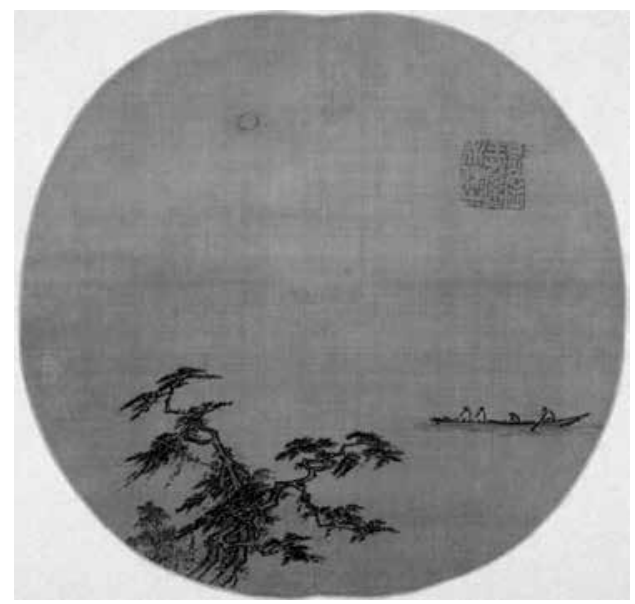

XIA Gui. Valtis upelyje po pušim ir pilnatim

tęsiančioje tolumoje. Šie elementai išreiškia žmogaus pagavą dangaus ir žemès begalybės atžvilgiu ir kartu beribi troškimą. Zhuangzi užsimena apie tai sakydamas: „Begalinio dangaus žydrynè, ar tai jo tikroji spalva? Ar jis toks tolimas ir ribų neturintis?" (Guo 2015).

Paveikslo pusiausvyros išraiška yra kartu vidinès sielos būsenos pusiausvyra, dèl šios išorinès subtilios pusiausvyros mes galime patirti sielos ramybę.

Yun estetinès dvasios įsikūnijimo paieškos Čiurlionio paveiksluose

Besigilindami i muzikalumo, poetikos ir harmonijos dvasia alsuojančius M. K. Čiurlionio paveikslus pamatysime, kad jo tapybine estetika iš esmès atitinka yun estetinès dvasios principus. Jo paveikslai neužgriūna visu regos smarku$\mathrm{mu}$, bet juose glūdi ir skleidžiasi stipri "neasmeninè" jausmų išraiškos galia. Besigèrint jo paveikslais galima intuityviai pajusti „už paveikslo“ slypinčią mįslinga, pranokstančią laiko ir erdvès išmatavimus žinia, ir iš šios „neišsemiamos 


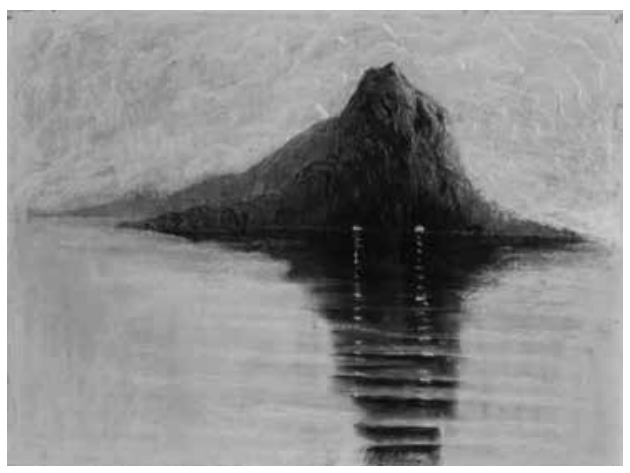

Ramybè, 1904

prasmès" perspektyvos galima sakyti, kad jo paveikslai atitinka ir tarsi îkūnija mūsų ivvairiais aspektais aptartą yun idèją. Dèl ribotos šio straipsnio apimties, remdamiesi yun dvasios išraiška paveiksluose kaip universaliu kriterijumi, analizei pasirinkome tuos Čiurlionio paveikslus, kuriuose, mūsų akimis žvelgiant, yra giliai išreikštas yun, ir pateikiame sąvo analizę argumentuodami, kodèl šiuose paveiksluose yra yun.

Pradedame analizę dar jo kūrybinio kelio pradžioje sukurtu labai simboliniu paveikslu „Ramybe்", kadangi jis iš pasirinktų ankstyvujų jo paveikslų mus dominančiu aspektu yra būdingiausias. Jis vienu metu ir atitinka pamatinius yun estetikos principus, ir neatitinka jų. Atitinka todèl, kad struktūriškai čia visiškai vyrauja neužpildyta erdvè. Beribejje jūroje čia stūkso didžiulis kalnas, o stebinčiojo link nusidriekęs įspūdingas kalno atspindys vandenyje kartu vertikaliai išplečia regos lauką. Horizontalus ir vertikalus vaizdavimas atitinka kinų kultūroje gyvybinga, metaforiškai vadinamą „keturių pusių“ idèją. Tik žvilgterèjus apima visa matančio, neaprèpiamo dangaus ir žemés vienišumo jausmas. Tačiau tradicinejje kinų tapybos estetikoje stebètoją pasiekiantis ir vizualiai arčiau esantis atspindys-šešèlis, šviesa ir spalvos kalno viduje neturi būti vaizduojami. Mįslinga šiame Čiurlionio paveiksle yra tai, kad jis, ne visiškai atitikdamas yun principus, kartu sukuria kinų peizažinès tapybos tradicijai labai artimą yun „neišbaigiamo dar daugiau", arba estetinès užuominos, neišsakymo pojūtį.

Kinų klasikinèje peizažo tapyboje yra daug paveikslų, kuriuose vaizduojamas jūroje stūksantis vienišas kalnas. Šiuo atvaizdu dažniausiai perteikiama žemiško pasaulio palikimo ir tolimos dvasinès kelionès intencija arba „,troškimas sutikti vandenyse ir kalnuose gyvenančias nežemiškas būtybes. Tačiau šis paveikslas kitoks, sulig pirmuoju žvilgsniu kyla ir tam tikras baimès pojūtis, tarytum mus akylai stebètuc pora akių ir stengtųsi ísiskverbti ì mūsų pačių nesuvoktą vidinę dvasios gelmę. Tai tuo pačiu ir tarsi akys su spontaniškai besiliejančiomis ašaromis, liūdnai reginčios pasaulị, nelyg perduotų tapytojo liūdną nežinomo ir mįslingo pasaulio pažinimą. Paveikslas perduoda tam tikrą beribių, sunkiai žodžiais nusakomų prasmių pojūti, tai galbūt žmogaus vienišumas, galbūt žmogaus paklydimas, o gal atodūsis dèl žmogaus likimo ar netgi nusivylimas pasauliu. Paveiksle išraiškingai naudojami paprasti kontūrai bei vaizdai sukuria neišsemiamą, mįslingų užuominu kupiną potekstę, o tai yun aukščiausias lygmuo - i baigtini kūrini perkelti neišsemiamą prasmę.

Kitas ì mūsų analizès lauką patekęs objektas yra iš Čiurlionio brandaus sonatinio periodo pasirinktas paveikslas 


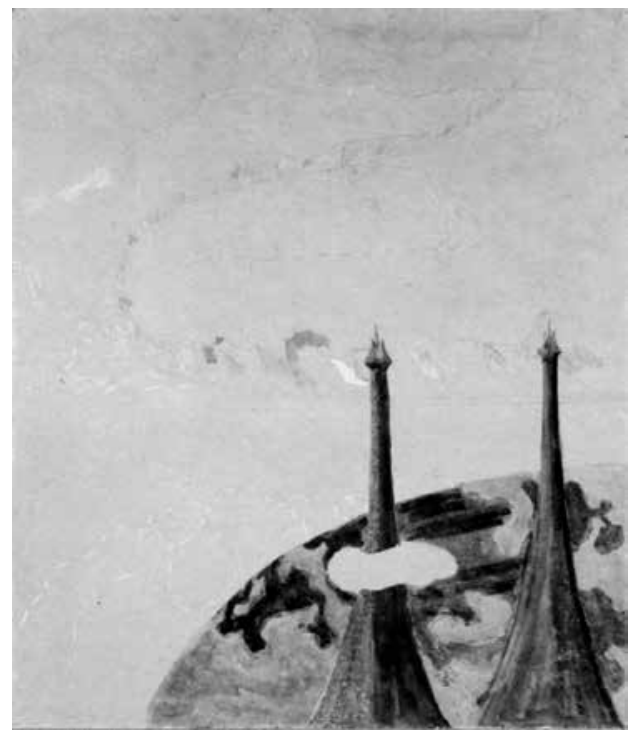

Finale (Sonata II), 1907

„Pavasario sonata", „FINALE (Sonata II, 1907)“. Lyginant ši paveikslą su Xia Gui anksčiau minètu kūriniu, galima sakyti, kad tai subtilumas, kuris igyvendintas skirtingais būdais, bet pasiekiamas tas pats rezultatas (kin. yi qu tong gong 异 曲同工). Artimesniame plane du bokštai atrodo kažkuo patrauklūs, tačiau žvilgsni toliau traukia didelè neužpildyta erdvè, kuri iš karto tarsi šaukia, vilioja mus judèti i priešais akis atsiveriančias tolumas. Tolumoje kaip gyvate vingiuojanti spalvotų vẻliavų virtinė veda mus į nepertraukimą kelionę, kurios kryptis priešais akis besiskleidžiantis ir viliojantis pažinimo galimybėmis beribis pasaulis. Spalvotos vèliavos nutapytos kinu tapybos tradicijai būdingu minimaliu teptuko prisilietimu, kuris tuo pačiu padeda nuimti viso piešinio apatinès dešinès dalies kompozicinio sprendimo sukurtą svori, tarsi subalansuoja besiskleidžianti nesvarumo jausmą ir leidžia

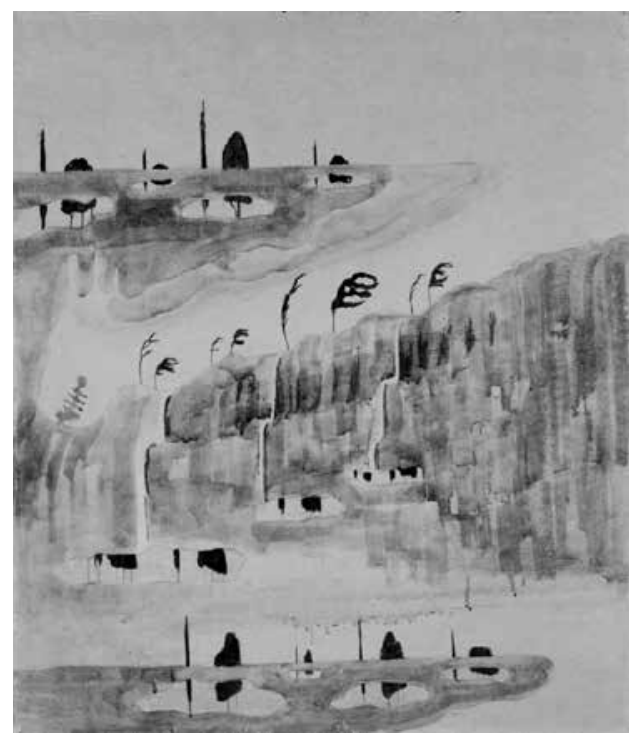

Allegro (Sonata II), 1907

piešiniui išlaikyti tam tikrą pusiausvyrą. Sukurto šio sonatinio periodo vaizdinio spalvos taip pat prèskos, o spalvotos vèliavèlès lyg ir matomos, bet lyg ir būtų paslèptos, suteikia žiūrovui nuosaikumo jausmą. Galbūt dailininkas nori išreikšti, kad tikroji kelionė yra pusiausvyra tarp regimo (to, kuris prieš akis) ir neregimo (nežinomo) pasaulių.

Ir pagaliau trečiasis i mūsų tyrimo lauką patekęs paveikslas yra iš tos pačios „Pavasario sonatos" pirmasis ciklo paveikslas ALLEGRO (Sonata II). Šio paveikslo svarbiausias bruožas yra spontaniškas, kupinas muzikalumo dvasios judèjimas - tai augalus judinantis vèjas, vandens srautai, palinkę nuo vètros medžiai, liudijantys qi energijos sklaidą. Dèl paveiksle ittaigiai panaudojamos didelès neužpildytos erdvės, sujungiančios skirtingas peizažo dalis, visas paveikslas tampa vientisa visuma. Tokia judejjimo, laiko tèkmès dvasios persmelkta Čiur- 
lionio paveikslo kompozicinè struktūra daro ji labai panašu i kinu paveikslus primenančio hieroglifo zhi 之 pavidalą (kurio vaizdinių sistema pradedama plètoti judant horizontalia linija iš kairès $\mathfrak{i}$ dešinę, vèliau šis ritminių struktūrų prisodrintas, muzikalių formų, primenančiu natas, judejjimas skleidžiasi isstrižai žemyn, atgal ir i kairę, galiausiai apačioje vèl užbaigiamas horizontaliu judesiu i dešinę), kur, kaip jau ir Xia Gui atveju, skirtingi meninių formų judejjimo ir ju komponavimo paveikslo erdvèje keliai duoda labai panašu muzikalu estetinio poveikio suvokejjui rezultatą. Kita vertus, šis, kaip ir anksčiau aptartas "Pavasario sonatos" ciklo paveikslas, yra artimi tradicinei kinu peizažo tapybai santūriu, netgi, sakyčiau, prislopintu spalvų koloritu.

Apibendrinant yun žvilgsni i šiuos aptartus tris Čiurlionio paveikslus kinu tapybos kontekste, galima be dvejoniu pasakyti, kad visi trys paveikslai pasižymi minètomis dviem svarbiausiomis yun sąvokai būdingomis savybèmis - subtilia elegancija ya 雅 ir "neišsemiamu daugiau“ you yu bu jin 有余不尽. Paveikslai taip pat atitinka mūsų išskirtus tris pamatinius yun tapybos principus: prèskumą dan 淡, neužpildytą erdvę ir judesi kong bai liu dong 空白流动 bei pusiausvyrą ping heng 平衡. Tačiau šitaip tiksliai ir analitiškai paminëjus šias savybes ir principus, verta prisiminti mūsu qi yun analizès išeities tašką - tradiciškai yun - tai estetinè kategorija, artima pačiai subtiliausiai Dvasinio Kelio Dao 道 idejjai savo neišreiškiamumu, neapibūdinamumu ir nesugaunamumu. Yun, kaip ir Dao, yra daugiau ir giliau nei aprépia žodžiai, todèl ju pagavai reikalingas išlavintas vidinis pojūtis, metu patirtimi ir sąmoningu darbu išaugintas mąstymas širdimi. Kinų meno eruditas wen ren (kuri, neturėdami tinkamesnio žodžio, mes vadiname „,intelektualu“) atpažista ir pajunta yun "muziką" meno kūrinyje iš pirmo žvilgsnio, iš pirmo pojūčio, ir vèlesnis racionalus ịvardijimas yra tik aproksimacija, tik pirštas, rodantis ị mènuli. Dèl to paveikslai kinų tradicineje kultūroje neretai tiksliausiai apibūdinami simbolių ir metaforu perpildyta poetine kalba, o subtiliausia poema visada tarsi sutalpina poetiniu vaizdiniu kupiną muzikalu paveikslą. Čiurlioniui, kaip ir kinų meno tradicijai, būdingas nepaprastai glaudus skirtingų meno rūšių - tapybos, kaligrafijos, muzikos ir poezijos - vidinis ryšys. Galbūt todèl ir Čiurlionis, tapydamas poetinès dvasios prisodrintus „sonatinius" paveikslus, negalëjo apsieiti be jam tokios svarbios muzikos, o ir muziką jis natūraliai galèjo paversti poetiškais paveikslais.

\section{IŠVADOS}

Taigi glaustai aptarę keliu pamatinių kinu estetikos kategoriju semantines prasmes, jų savitumą ir sąsajas su lietuvių dailininko Čiurlionio kūryba, galime pereiti prie apibendrinimų. Pirmiausia išsilavinusiems tradicinès kinų kultūros žmonèms wen ren (intelektualams), kultivavusiems iqvairias meno sritis, auten- 
tiško meno esmè glūdi „meistriškume“ yi 艺. Ju supratimu, jeigu menininkas prisiriša prie "technikos“ shu术, tuomet jis juda „mažuoju keliu“ xiao dao 小道. O „didysis kelias“, žinomas tik didiesiems meno meistrams, yra universalus ir visa pranokstantis. Yun idejja siekia lygmens, apibūdinamo kaip „neišsemiamas daugiau", o tai būtent ir yra išèjimas iš ịprastiniu vizualaus meno ribų: tokioje kūrybos strategijoje transcenduojami realistiški vaizdai, taip pat ir pats vizualumas, kadangi viskas sunkiai žodžiais nusakomu būdu meninès kūrybos procese nukreipiama į vidini širdies pasauli. Tapytojas tokiu būdu tarsi regi vidinès dvasios ir minties darbo rezultatus, o ne akimi matomus fizinius daiktus. $\mathrm{O}$ suvokejjas suvokdamas meno kūrinio estetiką pajunta tapytojo viziją ir susijungia su tapytojo vidiniu pasauliu, ir tai ivvyksta ne vien tik dèl žiūrèjimo akimis. Tai yra tam tikras „Dao“ 道, vidinés regos būdas. Todèl galima sakyti, kad yun yra ejjimas „Dao“ meno keliu.

Yun išreiškiamas lygmuo yra būtent Dao lygmuo, kurio panašias raiškos formas aptikome ir savo kūrybinès raiškos universalumu skirtingose meno srityse artimo kinų intelektualams Čiurlionio tapybos kūriniuose. Trijuose lyginamajai analizei pasirinktuose jo kūriniuose regi-

\section{Literatūra}

Binyon Laurence. 1911. The Flight of the Dragon. An Essay on the Theory and Practice of Arts in China and Japan, based on original sources. John Murray. Cahill James. 1961. The Six Laws and How to Read Them, Ars Orientalis 4: 372-381.

Chen Guying 陳鼓應. 1984. Laozi: pastabos ir mas lietuvių dailininko išskirtinis dėmesys mūsų aptartai vidinei rimčiai, erdvei, laikinėms dinamiškoms struktūroms, prèskumo estetikai, spalviniam santūrumui, muzikalumui, neišsakymui ir estetinei užuominai. Yun dvasia tiek kinu tradicinëje tapyboje, tiek ir Čiurlionio tapiniuose skleidžiasi vidine rimtimi (jam nebūdingos intensyvios aistros), taip pat turi prèskumo, jis nèra spalvotas ar itin rafinuotas. Nors ir paprastas, tačiau aprẻpiantis neišsibaigiančius virsmus. Yun siekiama išreikšti tylos prisilietima, taip pat begalybę. Zhuangzi žodžiais tariant: „Šventumą pasiekusio žmogaus širdis rami, dangaus ir žemès atspindys, visu daiktų veidrodis“" (Guo 2015). Yun siekiama išsilaisvinti iš pasaulio užimtumo, triukšmingumo, galiausiai pasiekti ypatingą vidinę rimtį. Ramiu ir neskubančiu žvilgsniu stebint pasaulio vyksmus pavaizduojamas visų daiktų grožis, galiausiai visi daiktai ir aš tampa viena. Susiliedami su gamta, surandame tikraji save. Šie pamatiniai Yun estetikos principai, kaip parodème analizëje, yra artimi brandžios Čiurlionio tapybos kūrybinei dvasiai ir reikalingi išsamesnès kompleksinès bei lyginamosios jo kūrybos ryšių su tradicine kinu estetika analizès, kurios atskiras perspektyvas mes tik mėginome apibrèžti šiame straipsnyje.

paaiškinimai 老子註譯及評價. Beijing: Zhonghua knygos 中華書局.

Chen Liangyun 陈良运. 2008. Kinu meno estetika 中 国艺术美学. Jiangxi meno technikos leidykla 江 西美术出版社.

Cohn William. 1948. Chinese Painting. Phaidon. 
Giles Herbert. 1905. An introduction to the history of Chinese pictorial art. Kelly\&Walsh.

Guo Qingfan 郭慶藩. 2015. Zhuang Zi komentary kolekcija 庄子集释. 3-iasis leid. 新編諸子集成. Beijing: Zhonghua knygos 中華書局.

Guo Shaoyu 郭紹虞. 1980. Song dinastijos išlikusios poezijos teorijos 宋詩話輯佚. Beijing: Zhonghua knygos 中華書局.

Ye Lang 叶朗. 1985. Kinu estetikos istorijos kontūrai 中国美学史大纲. Shanghai renmin leidykla 上海 人民出版社.

Lu Fusheng 卢辅圣. 1993. Kinu tapybos ir kaligrafijos pilnas rinkinys 中国书画全书. T. 1 第一册. Shanghai: Šanchajaus tapybos ir kaligrafijos leidykla 上海书画出版社.

Petrucci Raphaël. 1910. La Philosophie de la nature dans l'art d'Extrême-Orient. Henri Laurens, Paris.

Kiai-tseu-yuan houa tchouan.1918. Les enseignements de la peinture du jardin grand comme un grain de moutarde. Encyclopédie de la peinture chinoise. Henri Laurens, Paris.

Sirén Osvald. 2005. The Chinese on the Art of Painting: The Chinese on the Art of Painting: Texts by the Painter-Critics, from the Han through the Ch'ing Dynasties. Dover Publications.

Soper Alexander. 1949. The First Two Laws of Hsieh Ho, The Far Eastern Quarterly 8: 412-23.

Teng Gu 滕固. s. a. Kinu meno technikos mažoji istorija: Tang ir Song dinastiju istorija 中国美术小史: 唐宋绘画史. Šanchajaus tapybos ir kaligrafijos leidykla 上海书画出版社.

Waley Arthur. 1920. Chinese Philosophy of Art I : Note on the Six Methods, The Burlington Magazine for Connoiseurs 37: 309-310.
Wang Bi 王貆. 1781. Permainu knygos komentarai 周 易注. Keturių literatūros krypčių visų raštų rinkinys 四库全书.

Wang Wei 王维. 1961. Wang Wei raštu rinktinès egzegeze 王右丞集笺注. Sudarè Diancheng 赵殿 成 ZHAO. 1-asis leid. Shanghai: Šanchajaus klasikos raštų leidykla 上海古籍出版社.

Xie He 谢赫. 1993. Užrašai apie senosios tapybos sąvokas: Ivadas 古画品录·序文, Kinu tapybos ir kaligrafijos pilnas rinkinys 中国书画全书, sudare Fusheng 卢辅圣 LU. T. 1 第一册. Shanghai: Šanchajaus tapybos ir kaligrafijos leidykla 上海 书画出版社.

Xu Fuguan 徐复观. 2007. Kinu meno dvasia 中国艺 术精神. Guangxi universiteto leidykla 广西师范 大学出版社.

Xu Shangying 徐上瀛. 2010. Xi Shan Qin Kuang 溪 山琴况. 1673 m. spausdintas originalas, $2010 \mathrm{~m}$. fotografiju naujas leidimas. T. 10. 30 t. Liutnios muzikos rinkinys 琴曲集成. Beijing: Zhonghua knygos 中華書局.

Zhang Yanyuan 张彦远. 1993. Istoriniu tapybos kūrinių užrašai: diskusija apie tapybos šešis principus 历代名画记·论画六, Kinu tapybos ir kaligrafijos pilnas rinkinys 中国书画全书. T. 1 第一 册. Shanghai: Šanchajaus tapybos ir kaligrafijos leidykla 上海书画出版社.

Zhu Guangqian 朱光潜. 1982. Meno technikos straipsniu rinkinys 美术文集. Shanghajaus literatūros ir meno leidykla 上海文艺出版社.

Zong Baihua 宗白华. 2000. Meno lygmuo 艺境. Anhui švietimo leidykla 安徽教育出版社.

Iš kinų $k$. vertė dr. Julius VAITKEVIČIUS, Nankino universitetas, Kinija 